\title{
Chapter 37 \\ Human Resource Development and Gender Mainstreaming Under ADB-Funded Technical and Vocational Education and Training Project in Tajikistan
}

\author{
Eiko Izawa
}

The Strengthening Technical and Vocational Education and Training Project (the project/STVETP) was designed to promote a demand-driven, quality-assured, and flexible technical and vocational education and training (TVET) delivery system in Tajikistan. The Asian Development Bank (ADB) approved the project on 9 November 2015 for $\$ 34.0$ million (ADB financing of \$30.0 million, Clean Energy Fund financing of $\$ 2.0$ million, and counterpart funding from the Government of $\$ 2.0$ million). The project became effective in March 2016 and will close in February 2021. It is based on demonstrated market demand and is helping develop and implement industry-endorsed competency standards and competency-based training (CBT) through upgrading of the physical learning environment, training TVET teachers and masters, and strengthening the governance and management of the TVET system. To ensure market responsiveness, the project is promoting private sector participation in TVET policy, operations, and service delivery. ${ }^{1}$

The project is designed to include a strong gender mainstreaming element, promoting gender equity by directly addressing the problem of women's limited engagement in nontraditional higher paying occupations. The Ministry of Labor, Migration and Employment (MOLME) is the executing agency of the project. The project administration group (PAG) under MOLME is the implementing agency.

\footnotetext{
${ }^{1}$ Asian Development Bank. TA 9639-TAJ: Skills and Employability and Enhancement Project. Final Mid-Term Report. September 2019. Unpublished.
}

\section{E. Izawa $(\varangle)$}

Social Sector Division, Central West Asia Department, ADB, Manila, Philippines e-mail: eizawa@adb.org 


\section{Key Issues}

\section{Not Enough Jobs Being Created}

Growth in the economy and population is not resulting in parallel growth in job opportunities. The country's economy is expanding, with its gross domestic product (GDP) growth rate among the highest of neighboring countries. Between 2010 and 2018 , the average growth rate in GDP was $7.0 \%$, and it is expected to be $7.0 \%$ again in 2019 and $6.5 \%$ in $2020 .^{2}$ Demographics present Tajikistan with an opportunity in that $55.0 \%$ of the population is under 25 years of age, meaning there will be a growing working-age population. ${ }^{3}$ The working-age population in Tajikistan is expected to grow from $56.0 \%$ of the total population in 2010 to $62.8 \%$ in 2050 . However, this economic growth is not being accompanied by job creation, and within the economy, there are several structural issues. The average growth in GDP between 2003 and 2013 does not correspond with the growth of new jobs in that employment increased by only $2.1 \%$ yearly. ${ }^{4}$

There is an urgent need to address the unemployment crisis. Skills upgrading, basic skills training, quick turnaround certification, and access to credit to promote self-employment must be put in place as soon as possible. A comprehensive program for job creation needs to be designed and implemented. Jobs must be created in rural areas. The industry and services sectors need to establish more sustainable, labor-intensive small- and medium-sized enterprises.

\section{Labor Force Participation Is Low, Especially Among Women}

The overall labor force participation in Tajikistan is low relative to its comparators, especially for women. In 2016, the female labor force participation rate was only $40.6 \%$, which was 32.7 percentage points below the male labor force participation rate. In comparison, female labor force participation in Kazakhstan was $75.0 \%$, $60.0 \%$ in the Kyrgyz Republic, and $51.0 \%$ in Uzbekistan. ${ }^{5}$ Figure 37.1 shows that female participation lags behind that of males.

\section{Women Tend to Be Lower Paid}

Women tend to make up the majority of workers in agriculture. While agriculture accounts for only a quarter of GDP, $57.7 \%$ of the working force is employed in this sector, and very little has changed in this regard. In both 2010 and 2018, about $73 \%$ of the population lived in poor rural agricultural areas, where wages tend to be lower than in other sectors. ${ }^{6}$

\footnotetext{
${ }^{2}$ World Development Indicators, The World Bank https://datacatalog.worldbank.org/dataset/worlddevelopment-indicators accessed 2019-07-10.

${ }^{3}$ World Bank. 2014. "The Skills Road: Skills for Employability in Tajikistan." Washington, DC.

${ }^{4}$ International Bank for Reconstruction and Development/World Bank. 2017. "Jobs Diagnostic: Tajikistan: Strategic Framework for Jobs." Washington, DC.

${ }^{5}$ Ibid.

${ }^{6}$ World Development Indicators, World Bank. https://datacatalog.worldbank.org/dataset/world-dev elopment-indicators accessed 2019-09-06.
} 

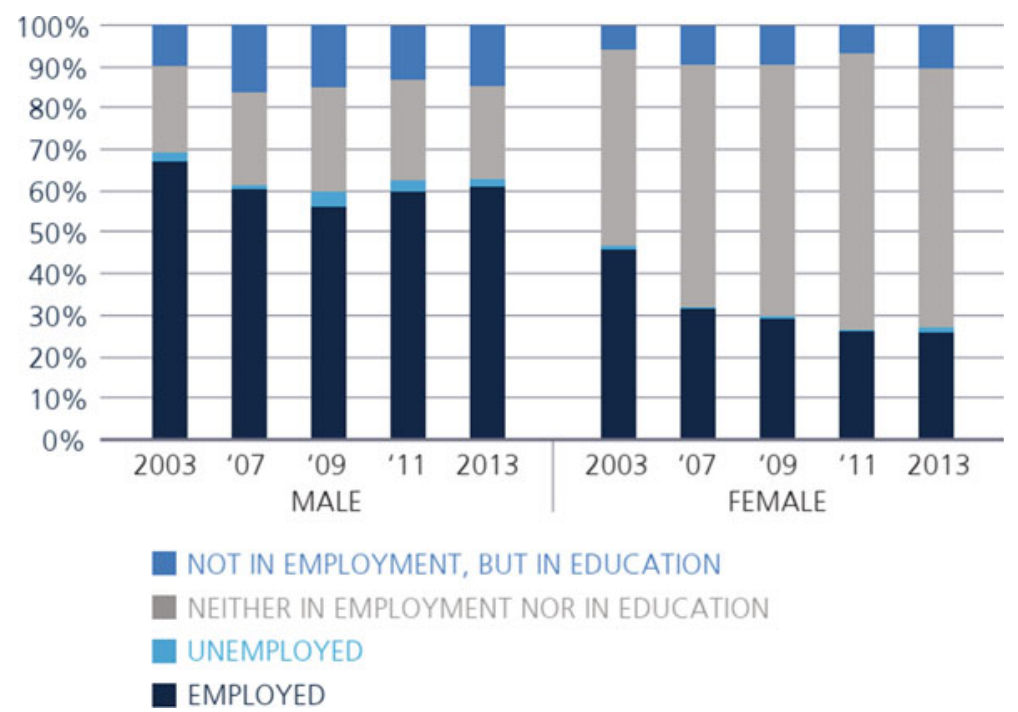

Source: World Bank. 2017 "Jobs Diagnostic: Tajikistan: Strategic Framework for Jobs"

Figure 37.1 Labor force status as a percentage of total working-age population males and females 2003-2013

The informal sector represents a large and growing source of jobs in Tajikistan, but informal workers tend to be poorer than formal sector workers. While $18 \%$ of informal workers are in the poorest quintile of household consumption, only $11 \%$ of formal workers are in the bottom quintile. ${ }^{7}$ Informal workers are more likely to live in rural areas and are more likely to work in construction and agriculture. Youth and females make up a large percentage of the informal workers with jobs that offer significantly less protection and poorer working conditions.

\section{Challenges in the Technical and Vocational Education and Training System}

The TVET system in Tajikistan is largely supply-driven. Most course structure and content are outdated, resulting in a mismatch between graduate skills and labor market demand. Ineffective engagement of private sector partners in TVET, both employers and private trainers, is a key problem. Skills gaps to address climate change are also an issue. Most TVET institutions have obsolete and inadequate equipment, dilapidated school buildings, and poorly maintained dormitories. The condition of physical facilities and the lack of modern curricula reinforce the generally low social image of TVET, contributing to the system's inability to attract students, particularly females.

Primary TVET suffers from deficiencies in both quality and quantity. The total enrollment in 63 lyceums in 2014 was only 21,593 students, of whom $18 \%$ were girls. The average enrollment size of 343 students per lyceum results in low studentteacher ratios (9:1), high unit cost (TJS1,400 per student per year compared with

\footnotetext{
${ }^{7}$ World Bank. 2014. "The Skills Road: Skills for Employability in Tajikistan.” Washington, DC.
} 
TJS900 in general education), and a low percentage share of internally generated funds $(22 \%)$ to total funding. ${ }^{8}$

Weak faculty development has resulted in inadequately trained teaching staff. The salary scale of TVET teachers and masters remains very low compared with other civil servants, and employees in the industry and services sectors. Investment in TVET teacher salaries and training is required to build capacity, modernize technical and training skills, match skills to emerging market needs, and increase retention of qualified TVET teachers and masters. Efforts are also required to attract more female teachers and masters to act as role models for female trainees.

\section{Gender Mainstreaming}

The project targets to significantly increase female enrollment in nontraditional TVET courses through a number of strategies. Tajikistan has a relatively traditional culture when it comes to the role of women in society, and to overcome this tradition it was determined that there will need to be a multipronged approach to encourage more females to want to work in nontraditional jobs. An intensive and extensive social marketing campaign was initiated to encourage parents and communities to send their girls for training in nontraditional occupations. The project is also providing stipends to encourage girls to enroll in and train for nontraditional occupations. To make female trainees feel comfortable within the living environment while attending courses, exclusively female sections are being created in dormitories. Also, femalefriendly facilities are being installed in school buildings such as gender-segregated toilets. To provide positive role models for girls, the number of female teachers and masters in nontraditional courses, and the number of women in the management staff of TVET institutions are being increased.

One of the key project activities is the Gender Equity Model Program (GEMP), which is the overall program for the project's gender mainstreaming including a survey, training, awareness-raising, gender networking, and impact assessment. The GEMP will further address low female participation in TVET, which will demonstrate the effectiveness of temporary special measures in encouraging women and girls to get into nontraditional occupations.

\footnotetext{
${ }^{8}$ ADB. 2013. Technical Assistance to the Republic of Tajikistan for Preparing the Strengthening Private Sector Participation in Technical and Vocational Education and Training Project. Manila (TA 8546-TAJ).
} 


\section{TVET System Methodology Modernized}

To ensure that new methodologies for TVET reflect basic core messages on gender equality, a modular training guide was produced and adapted to each of $17 \mathrm{occu}-$ pations for curriculum and learning materials developers. To adapt each of the 17 occupations being developed, the project hired an international gender expert to conduct trainings for those who draft curricula and learning materials. At least $50 \%$ of the members of each of the 17 groups of curriculum and learning materials developers (composed of industry experts and TVET curriculum experts) have undergone gender orientation/training. All Engineering Pedagogical College in Dushanbe staff (49), all Center for Training Methodology and Monitoring of Education Quality trainers, all members of each of the five industry working groups, all nominated expert panels, all members of each industry association, and all members of industry advisory committees (IACs) of each lyceum have undergone gender orientation to understand gender issues relevant to their TVET areas.

The participation of women experts in the industry expert panels and curriculum expert panels was ensured by having the PAG Gender and Education Specialist jointly with the CBT Coordinator and the Industry Partnership Specialist always consider the participation of women in all panels during the formation and functioning of the groups. In the five sectoral working groups under the ministries and state committees, of a total of 40 members, 9 or $22.5 \%$ are women, and of 195 members of industry expert panels, 60 or $30.8 \%$ are women. The project is working toward having at least $25 \%$ of the technical experts trained and accredited as competency assessors be women.

Gender analysis of assessment results is being undertaken to identify factors that explain differences in assessment results, as well as to determine recommendations to address gender issues that have emerged. To do this, student assessments will be disaggregated by sex with a particular emphasis on female students enrolled in nontraditional courses.

\section{Physical Learning Facilities in Selected TVET Institutions Upgraded}

To ensure that each dormitory rehabilitated has a separate and secure section for females with appropriate equipment and facilities, each of the contracts with different construction companies specifies that these conditions must be met. The PAG legal advisor, Gender and Education Specialist, National Regional Centers (RCs), and GEMP Coordinator conducted special information sessions or construction workers. All rehabilitated classrooms and workshop buildings will have separate toilet facilities for females with doors that ensure privacy and security. 


\section{Access to Quality TVET Programs Improved}

To ensure participation of women as TVET teachers and masters in competencybased trainings, the goal was to have at least $35 \%$ of all TVET teachers and $25 \%$ of the masters in project lyceums and adult learning centers trained on competencybased teaching methodology be women. To achieve this goal the PAG staff pays special attention to the implementation of this target with the result that women in pilot lyceums, RCs, and IACs constituted from 33 to $55 \%$ of the participants who underwent training on CBT methodology.

To increase female enrollment in nontraditional occupations, intensive community awareness-raising activities were undertaken. The goal is to have at least $30 \%$ of students enrolled in diploma and certificate courses in project lyceums be females and at least $25 \%$ of students enrolled in 12 nontraditional occupations be females. To facilitate the development of awareness of nontraditional occupations, an advertising firm was hired. In the early stage of the project implementation period, the project has reached nine districts and cities covering nearly 2,000 parents and community leaders. Three kinds of brochures and leaflets were drafted, published, and distributed among the population, community leaders, and RCs, and used as handouts during trainings and round tables. The publications on GEMP were done in three languages: Tajik (6,000 copies), Russian (100 copies), and English (100 copies). One film on nontraditional occupations was produced and used during advocacy campaigns. Hired in September 2018, the local implementation firm Peshsaf has continued with this work, resulting in a number of articles appearing in newspapers and magazines, and on television and radio.

The goals are to have the average enrollment of females in 12 CBT nontraditional courses in the five pilot TVET institutions under the GEMP increased to $25 \%$ of total enrollment by the third quarter of 2020 and to have at least $50 \%$ of GEMP graduates certified in nontraditional occupations. To this end, 2,230 women and girls, including those who are poor and vulnerable, in selected lyceums are being fully supported in the GEMP through stipends and priority placements in rehabilitated dormitories. To facilitate the offering of stipends and priority placements, MOLME signed a decree on 5 March 2018. As of September 2019, there were 873 female (39\%) GEMP beneficiaries. To speed up the process, the project announced a contest for the best gender advocate. Students are receiving stipends upon receiving relevant certification documents. The process of payment for teachers who provided 3-month services in the courses, which were not budgeted, has started.

The industry partnership specialists (international and national), while working to forge partnerships with industries, are attempting to ensure the employment of female graduates of nontraditional courses, with the goal that at least $50 \%$ of all project partner enterprises employ female graduates in nontraditional occupations.

The project is attempting to ensure there is significant participation of women in its Market-Responsive and Inclusive Training Program, which provides skills training beyond the 17 priority occupation skills, targeting youth in 29 districts. As of June 
2019 , the total number of trained people through this program was 510,277 , of whom $54,3 \%$ were women.

\section{Governance and Management of TVET System Strengthened}

To project the importance of having women in leadership roles, the project has hired 27 women out of a total of 87 PAG staff or 31\%. All PAG officials, staff, and consultants are familiar with the project Gender Action Plan and are aware of their specific roles relevant to the achievement of these targets. This was achieved through conducting trainings, workshops, and gender sessions for different target groups in which PAG officials, staff, and consultants participate and as well during staff meetings.

The goal is to have at least $20 \%$ female membership in each IAC established in each lyceum receiving additional support from GEMP. The total number of IAC members is 125 , of whom 28 or $22.4 \%$ are women. All women management staff in each project lyceum are to participate in trainings on modern educational management approaches. Of the 2,634 participants who took part in the CBT trainings, 798 or $30.3 \%$ were women. Gender indicators have been included in the monitoring framework for the project with the baseline and tracer studies, which included the requirement to collect additional gender-disaggregated data. Official statistics are being collected from MOLME on the enrollment of students and employment of graduates, as well as gender analysis of trends in the employability of TVET graduates. For the 2018/19 school year, the total number of students in lyceums was 22,903 , of whom 5,075 or $22 \%$ were girls. This compares with 21,593 students and $18 \%$ females in 2014.

\section{Conclusion}

The STVETP is a little over halfway completed, has shown good potential for addressing several of the issues related to TVET in Tajikistan, and is showing good progress at ensuring that more females are trained in and assume jobs in higher paying nontraditional technical jobs. The next 3 years will be critical in ensuring that the activities that have been initiated show whether gains will be made in the number of females being trained in lyceums across the country.

Link to the presentation material: https://events.development.asia/materials/201 90828/energy-human-resource-development-and-gender-mainstreaming-underadb-funded-tvet. 


\section{References}

Asian Development Bank. (2019, September) TA 9639-TAJ: Skills and Employability and Enhancement Project. Final Mid-Term Report. Unpublished.

Asian Development Bank. (2013). Technical Assistance to the Republic of Tajikistan for Preparing the Strengthening Private Sector Participation in Technical and Vocational Education and Training Project. Manila (TA 8546-TAJ).

International Bank for Reconstruction and Development/World Bank. (2017). Jobs diagnostic: Tajikistan: strategic framework for jobs Washington, DC.

World Development Indicators, The World Bank. Retrieved July 10, 2019, from https://datacatalog. worldbank.org/dataset/world-development-indicators.

World Bank. (2014). The skills road: Skills for employability in Tajikistan. Washington, DC.

The views expressed in this Chapter are those of the authors and do not necessarily reflect the views and policies of the Asian Development Bank (ADB) or its Board of Governors or the governments they represent.

ADB does not guarantee the accuracy of the data included in this Chapter and accepts no responsibility for any consequence of their use. The mention of specific companies or products of manufacturers does not imply that they are endorsed or recommended by ADB in preference to others of a similar nature that are not mentioned.

By making any designation of or reference to a particular territory or geographic area, or by using the term "country" in this Chapter, ADB does not intend to make any judgments as to the legal or other status of any territory or area.

This work is available under the Creative Commons Attribution 3.0 IGO license (CC BY 3.0 IGO) https://creativecommons.org/licenses/by/3.0/igo/. By using the content of this Chapter, you agree to be bound by the terms of this license. For attribution, translations, adaptations, and permissions, please read the provisions and terms of use at https://www.adb.org/terms-use\#openac cess.

This CC license does not apply to non-ADB copyright materials in this Chapter. If the material is attributed to another source, please contact the copyright owner or publisher of that source for permission to reproduce it. ADB cannot be held liable for any claims that arise as a result of your use of the material.

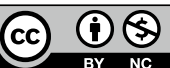

